\title{
Antimicrobial activity and phytochemical prospection of vegetal extracts of Ocotea silvestris Vattimo-Gil and Ocotea diospyrifolia (Meisn.) against serotypes of Salmonella of poultry origin
}

\author{
Atividade antimicrobiana e prospecção fitoquímica dos extratos vegetais de "Ocotea \\ silvestris" Vattimo-Gil e "Ocotea diospyrifolia" (Meisn.) frente sorotipos de \\ "Salmonella" de origem avícola
}

\section{WEBER, Laís Dayane ${ }^{1}$; SCUR, Mayara Camila ${ }^{1}$; SOUZA, Juliete Gomes de Lara de ${ }^{1}$; TOLEDO, Adrieli Gorlin ${ }^{1}$; PINTO, Fabiana Gisele da Silva ${ }^{1 *}$}

\footnotetext{
${ }^{1}$ Universidade Estadual do Oeste do Paraná, Laboratório de Biotecnologia Programa de Conservação e Gestão de Recursos Naturais Cascavel, Paraná, Brasil.

*Endereço para correspondência: fabiana.pinto@unioeste.br
}

\section{RESUMO}

O objetivo deste trabalho foi avaliar a atividade antimicrobiana dos extratos vegetais de Ocotea silvestris Vattimo-Gil e Ocotea diospyrifolia (Meisn.) Mez frente a 10 sorotipos de Salmonella enterica de origem avícola de maior incidência na região Oeste do Paraná, bem como realizar a triagem fitoquímica dos compostos de Ocotea silvestris Vattimo-Gil e Ocotea diospyrifolia (Meisn.). Após a obtenção do extrato aquoso e dos extratos orgânicos (álcool etílico, acetato de etila e hexano) foram determinadas a concentração inibitória mínima (MIC) e a concentração bactericida mínima (MBC) por meio da técnica de microdiluição em caldo. A prospecção fitoquímica foi realizada de acordo com metodologia qualitativa de precipitação e colorimetria. Os extratos apresentaram atividade inibitória e bactericida em diferentes concentrações (200 a $25 \mathrm{mg} . \mathrm{mL}^{-1}$ ) frente aos sorotipos de Salmonella, variando de acordo com o solvente extrator. O extrato acetato de etila apresentou os melhores resultados, seguido pelo extrato alcoólico, aquoso e hexânico. Ressalta-se que estudos de atividade antimicrobiana com extrato vegetais dentro do gênero Ocotea são escassos, contudo, a família Lauraceae apresenta significativas atividades biológicas, principalmente relacionadas aos seus óleos essenciais. A prospecção fitoquímica detectou a presença de esteróides e alcalóides em ambas as espécies de Ocotea, podendo justificar o potencial antimicrobiano encontrado para os sorotipos de Salmonella. Conclui-se que estas plantas representam uma alternativa para o controle de Salmonella no setor avícola, refletindo uma nova perspectiva para estudos com produtos naturais.

Palavras-chave: bactericida, bacteriostático, Lauraceae, microdiluição

\section{SUMMARY}

The aim of this work was to evaluate the antimicrobial activity of plant extracts Ocotea silvestris Vattimo-Gil and Ocotea diospyrifolia (Meisn.) Mez against 10 serotypes Salmonella enterica of poultry origin of the highest incidence in the western region of Paraná, as well as to perform the phytochemical screening of the compounds of the two species. After obtaining the aqueous extract and the organic extracts (ethyl alcohol, ethyl acetate and hexane) was determined Minimum Inhibitory Concentration (MIC) and Minimum Bactericidal Concentration (MBC) by technique microdilution broth. Phytochemical prospecting performed according to qualitative methodology of precipitation and colorimetry. The extracts presented inhibitory and bactericidal activity in different concentrations (200 to $25 \mathrm{mg} \cdot \mathrm{mL}^{-1}$ ) against the serotypes of Salmonella, varying according to the solvent extractor. The ethyl acetate extract presented the best results, 
followed by the alcoholic, aqueous and hexane extract. It is noteworthy that studies of antimicrobial activity with vegetable extract within the genus Ocotea are scarce, however, the Lauraceae family presents significant biological activities, mainly related to its essential oils. Phytochemical prospecting detected the presence of steroids and alkaloids in both Ocotea species, which may justify the antimicrobial potential found for Salmonella serotypes. It is concluded that these plants represent an alternative for the control of Salmonella in the poultry sector, reflecting a new perspective for studies with natural products.

Keywords: bactericidal, bacteriostatic, Lauraceae, microdilution

\section{INTRODUCION}

Poultry is a productive chain in transition, due to new technological standards required to increase productivity, and Brazil in this context, stands out as the leading export and the world's second largest producer of poultry meat (BELUSSO \& HESPANHOL，2010; CARDOSO \& TESSARI, 2015).

In view of this scenario, Salmonella represents a frequent threat to the poultry industry, since in addition to the resistance developed to the current antimicrobials, it is also considered one of the main pathogens in the contamination of chicken meat during the production, since the birds are natural reservoirs of this bacterium (SILVA \& GIBBS, 2012; THAI et al., 2012; CAMILOTTI et al., 2015).

In this context, it is extremely important to evaluate alternative products, such as plant extracts, for its antimicrobial potential against poultry Salmonella, becoming important in the study of alternative compounds for the control of salmonellosis in aviaries.
Within the Lauraceae family, the genus Ocotea, a native Brazilian species with proven biological activities, stands out the presence of antioxidant properties (OLIVERO-VERBEL et al., 2010), antibacterial (CANSIAN et al., 2010a), antifungal (CASTRO \& LIMA, 2011), inseticidal (PRIETO et al., 2010), antiinflamatory (BARRERA \& SUAREZ, 2011), anticholinesterase (YAMAGUCHI et al., 2012), among others.

The aim this manuscript to evaluate the antimicrobial activity of vegetal extracts of Ocotea silvestris Vattimo-Gil and Ocotea diospyrifolia (Meisn.) Mez. compared to serotypes of Salmonella enterica with the highest occurrence in the last 10 years in poultry in the Western region of Paraná, as well as to carry out the phytochemical screening of the plants studied.

\section{MATERIAL AND METHODS}

The leaves of Ocotea silvestris (black cinnamon) and Ocotea diospyrifolia (yellow cinnamon) were collected at the Santa Maria Natural Patrimony Private Reserve (RPPN Santa Maria) and Fazenda São José, Foz do Iguaçu, PR, Brazil. The collections were always carried out in the morning between the months of March and May of 2011, according to the natural distribution and availability of the species. An exsicata of each plant was sent to the Herbarium of the State University of the West of Paraná (UNOP) for botanical identification and registration of the voucher species under the numbers 7318, 7253 (Ocotea silvestris) e 7252 (Ocotea diospyrifolia).

After collection and identification, the leaves were dried in an oven with air circulation at $40^{\circ} \mathrm{C}$ for 48 hours and crushed in an electric grinder of $0.42 \mathrm{~mm}$ 
granulometry. The powder of each plant was stored in amber glass, hermetically sealed at $4^{\circ} \mathrm{C}$.

Strains of Salmonella enterica isolated from fresh carcasses of commercial broiler: Enteritidis, Infantis, Typhimurium, Heidelberg, Mbandaka, Give, Saintpaul, Ohio, Gallinarum e Agona, were isolated and assigned to research by the Mercolab laboratory. These strains were chosen due to the highest incidence of research during 10 years of research in our laboratory.

The serotypes were previously inoculated in Brain Heart Infusion Broth (BHI) and incubated at $35^{\circ} \mathrm{C}$ for 16 to 18 hours. Then innoculated in Müller Hinton Agar (MHA) and again incubated at $35^{\circ} \mathrm{C}$ for 16 hours. Three viable colonies were selected, diluted in saline solution $(0.85 \%)$ until reaching a concentration of $1 \times 10^{8}$ UFC.mL ${ }^{-1}$ on the 0.5 MacFarland scale. Subsequently, dilutions were performed in order to obtain an inoculum in the concentration of $1 \times 10^{5}$ UFC. $\mathrm{mL}^{-1}$.

The tests were based on broth microdilution technique according toWeber et al. (2014). Aliquots $(10 \mu \mathrm{L})$ of the dilution were distributed into 96well microtiter plates containing $150 \mu \mathrm{l}$ of MHA, with the previous addition of the extracts. The extracts were diluted in concentrations between 0.09 and 200 $\mathrm{mg} \cdot \mathrm{mL}^{-1}$. The plates were incubated at $37^{\circ} \mathrm{C}$ for 18 hours.

To evaluate antimicrobial activity, a 10 $\mu \mathrm{L}$ aliquot of $0.5 \%$ triphenyltetrazolium chloride (TTC) was added and maintained at $37^{\circ} \mathrm{C}$ for reading after 3 hours of incubation. The minimum inhibitory concentration (MIC) reading was performed by changing the color of the medium, in which the wells that showed inhibitory activity remained colorless, while wells in which microbial growth showed red coloration.
The determination of the minimal bactericidal concentration (MBC) was performed according to a methodology proposed by Weber et al. (2014) by inoculating $10 \mu \mathrm{l}$ of each dilution in MHA and incubated at $35^{\circ} \mathrm{C}$ for 24 hours. The presence of colonies was considered an evidence of bacteriostatic activity, whereas the absence of colonies indicated the bactericidal activity. MBC was considered the lowest concentration of the extract in study capable of promoting the death of the inoculum. As a positive control, chloramphenicol 100 mg. $\mathrm{mL}^{-1}$ and negative control sterile distilled water were used. The tests were performed in triplicate.

Phytochemical prospecting was carried out according to a qualitative methodology proposed by Matos (1997). Thus, we used: A) acidification and alkalinization test for the detection of anthocyanins and catechins; B) fluorescence test under UV light for coumarins; C) Lieberman-Burchard reagent (acetic anhydride + concentrated sulfuric acid) for steroids and triterpenoids; D) ferric chloride for single phenols and tannins, $\mathrm{Na}_{2} \mathrm{CO}_{3}$ for flavones; E) Shinoda reagent (concentrated $\mathrm{HCl}$ and granulated magnesium tape) for flavonoids and xanthones; $\mathrm{F}$ ) the $\mathrm{pH}$ variation test (with sodium hydroxide and sulfuric acid) for flavonoids, flavanones and flavanones; and $\mathrm{H}$ ) with chloroform and distilled water for saponins.

\section{RESULTS AND DISCUSSION}

The results demonstrated in Table 1 indicate that all extracts tested of $O$. silvestris presented antimicrobial activity against serotypes of $S$. enterica, with minimum inhibitory concentration (MIC). However, in the tests with 
hexanic extract (HE) and the aqueous extract (AqE) no bactericidal activity (MBC) was found for the S. enterica serotypes tested.

The alcoholic extract (AE) and ethyl acetate extract (EAE) presented the lowest MIC values, ranging from 50 to 25 mg.mL ${ }^{-1}$. AE presented MBC ranging from 100 to $50 \mathrm{mg} \cdot \mathrm{mL}^{-1}$ for all serotypes, EAE showed MBC of 100 mg.mL ${ }^{-1}$ against all serotypes tested, except for $S$. Naintpaul that presented MBC of $200 \mathrm{mg} \cdot \mathrm{mL}^{-1}$. Similar results were also observed for $O$. diospyrifolia extracts (Table 2).

Table 1. Minimum inhibitory concentration (MIC) and minimum bactericidal concentration (MBC) in mg. $\mathrm{mL}^{-1}$ of the extracts of Ocotea silvestris Vattimo-Gil against Salmonella serotypes.

\begin{tabular}{|c|c|c|c|c|c|c|c|c|c|}
\hline \multirow{2}{*}{$\begin{array}{l}\text { Serotypes of } \\
\text { Salmonella }\end{array}$} & \multirow{2}{*}{ CLO } & \multicolumn{2}{|c|}{$\mathrm{AqE}$} & \multicolumn{2}{|c|}{$\mathrm{AE}$} & \multicolumn{2}{|c|}{ EAE } & \multicolumn{2}{|c|}{$\mathrm{HE}$} \\
\hline & & $\mathrm{MIC}$ & $\mathrm{MBC}$ & $\mathrm{MIC}$ & $\mathrm{MBC}$ & MIC & $\mathrm{MBC}$ & $\mathrm{MIC}$ & $\mathrm{MBC}$ \\
\hline S. Enteritidis & 100 & 100 & $\mathrm{Na}$ & 25 & 100 & 25 & 100 & 200 & $\mathrm{Na}$ \\
\hline$S$. Infantis & 100 & 100 & $\mathrm{Na}$ & 25 & 50 & 50 & 100 & 200 & $\mathrm{Na}$ \\
\hline S. Typhimurium & 100 & 100 & $\mathrm{Na}$ & 50 & 100 & 25 & 100 & 100 & $\mathrm{Na}$ \\
\hline$S$. Heidelberg & 100 & 100 & $\mathrm{Na}$ & 25 & 50 & 25 & 100 & 100 & $\mathrm{Na}$ \\
\hline S. Mbandaka & 100 & 50 & $\mathrm{Na}$ & 50 & 50 & 50 & 100 & 100 & $\mathrm{Na}$ \\
\hline$S$. Give & 100 & 100 & $\mathrm{Na}$ & 50 & 50 & 50 & 100 & 100 & $\mathrm{Na}$ \\
\hline S. Naintpaul & 100 & 100 & $\mathrm{Na}$ & 25 & 50 & 50 & 200 & 200 & $\mathrm{Na}$ \\
\hline S.Ohio & 100 & 100 & $\mathrm{Na}$ & 25 & 50 & 50 & 100 & 100 & $\mathrm{Na}$ \\
\hline S. Gallinarum & 100 & 100 & $\mathrm{Na}$ & 50 & 100 & 50 & 100 & 100 & $\mathrm{Na}$ \\
\hline S.Agona & 100 & 50 & $\mathrm{Na}$ & 50 & 100 & 50 & 100 & 100 & $\mathrm{Na}$ \\
\hline
\end{tabular}

$\mathrm{AqE}=$ Aqueous extract; $\mathrm{AE}=$ Alcoholic Extract; EAE = Ethyl Acetate Extract; HE = Hexane extract. $\mathrm{CLO}=$ chloramphenicol $100 \mathrm{mg} \cdot \mathrm{mL}^{-1} ;(\mathrm{Na})=$ No Activity.

Table 2. Minimum inhibitory concentration (MIC) and Minimum bactericidal concentration (MBC) in mg. $\mathrm{mL}^{-1}$ of the extracts Ocotea diospyrifolia (Meisn.) Mez against Salmonella serotypes.

\begin{tabular}{lcrrrrrrrr}
\hline \multirow{2}{*}{$\begin{array}{l}\text { Serotypes of } \\
\text { Salmonella }\end{array}$} & \multirow{2}{*}{ CLO } & \multicolumn{2}{c}{ AqE } & \multicolumn{2}{c}{ AE } & \multicolumn{2}{c}{ EAE } & \multicolumn{2}{c}{ HE } \\
\cline { 3 - 10 } & & MIC & MBC & MIC & MBC & MIC & MBC & MIC & MBC \\
\hline S. Enteretidis & 100 & 50 & $\mathrm{Na}$ & 50 & 200 & 50 & 100 & 200 & $\mathrm{Na}$ \\
S. Infantis & 100 & 50 & $\mathrm{Na}$ & 50 & 200 & 50 & 100 & 200 & $\mathrm{Na}$ \\
S. Typhimurium & 100 & 50 & $\mathrm{Na}$ & 50 & 200 & 25 & 100 & 100 & $\mathrm{Na}$ \\
S. Heidelberg & 100 & 100 & $\mathrm{Na}$ & 50 & 200 & 50 & 200 & 100 & $\mathrm{Na}$ \\
S. Mbandaka & 100 & 50 & $\mathrm{Na}$ & 100 & 200 & 50 & 100 & 100 & $\mathrm{Na}$ \\
S. Give & 100 & 100 & $\mathrm{Na}$ & 100 & 200 & 50 & 200 & 100 & $\mathrm{Na}$ \\
S. Naintpaul & 100 & 100 & $\mathrm{Na}$ & 100 & 200 & 50 & 100 & 200 & $\mathrm{Na}$ \\
S. Ohio & 100 & 100 & $\mathrm{Na}$ & 100 & 200 & 50 & 200 & 200 & $\mathrm{Na}$ \\
S. Gallinarum & 100 & 100 & $\mathrm{Na}$ & 100 & 200 & 50 & 100 & 100 & $\mathrm{Na}$ \\
S.Agona & 100 & 50 & $\mathrm{Na}$ & 50 & 200 & 25 & 100 & 100 & $\mathrm{Na}$ \\
\hline AqE
\end{tabular}

$\mathrm{AqE}=$ Aqueous extract; $\mathrm{AE}=$ Alcoholic Extract; EAE = Ethyl Acetate Extract; $\mathrm{HE}=$ Hexane extract. $\mathrm{CLO}=$ chloramphenicol $100 \mathrm{mg} \cdot \mathrm{mL}^{-1} ;(\mathrm{Na})=$ No Activity . 
Based on the MIC, the range of susceptibility of the tested serotypes against $\mathrm{AqE}$ and $\mathrm{HE}$, respectively. No bactericidal activity (MBC) of these extracts was checked for the present concentrations tested.

The extracts tested presented antimicrobial activity in concentrations close to the antimicrobial standard chloramphenicol at $100 \mathrm{mg} \cdot \mathrm{mL}^{-1}$ used as positive control. Thus, the extracts were efficient, as the standard antibiotic, in inhibiting the growth of microbial strains.

In relation to the absence of bactericidal activity for AqE and $\mathrm{HE}$ in the two species, data found in the literature indicate that mechanisms such as some types of efflux pumps found in strains of the Enterobacteriaceae family, such as Salmonella and Pseudomonas aeruginosa are involved in the resistance of Gram negative for most natural products (KUETE et al., 2011). These processes or mechanisms act as a mechanical barrier against antibacterials, whether natural as extracts and essential oils or chemicals.

It is noteworthy that studies of antimicrobial activity with vegetable extract within the genus Ocotea are scarce. However, the Lauraceae family presents significant biological activities, mainly related to its essential oils. Cansian et al. (2010b) evaluated the antimicrobial activity of Cinnamomum camphora (Lauraceae) essential oil and found that it had a MIC of $1.0 \mathrm{mg} \cdot \mathrm{mL}^{-1}$ for Salmonella Choleraesuis (ATCC 10708). Studies by Mith et al. (2014), showed high antimicrobial activity for two species of cinnamon (Cinnamomum cassia and Cinnamomum verum) against serotypes of $S$. Typhimurium (ATCC 14028) and $S$. Typhimurium (S0584), showing MIC and MBC ranging from 0.25 and $1.0 \mu \mathrm{L} \cdot \mathrm{mL}^{-1}$.
In relation to plant extracts, Nanasombat \& Lohasupthawee (2005) tested the ethanolic extract of Cinnamomum verum in 9 Salmonella serotypes, which presented MIC ranging from 83.3 mg. $\mathrm{mL}^{-1}$ to $166.7 \mathrm{mg} . \mathrm{mL}^{-1}$, agreeing with our studies. Alzoreky \& Nakahara (2003) tested the extract of the bark of $C$. cassia against the $S$. Infantis serotype by disc diffusion and agar dilution method, however, by test in disk diffusion no antimicrobial activity was verified, but the extract had MIC of $2.64 \mathrm{mg} \cdot \mathrm{mL}^{-1}$ using the agar dilution method. This fact can be justified, due to the agar dilution methodology, to allow greater solubility and diffusion of the bioactive components of the extract. The broth microdilution methodology used in our study presents more reliable quantitative results, since this technique is not influenced by the growth rate of the microorganisms and presents its greater sensitivity to minimum amounts of reagent (BONA et al., 2014; OSTROSKY et al.; 2008).

The present study indicated that extracts obtained from the leaf of the tested species had secondary metabolites (Table 3) with antimicrobial potential and that the extracts of both species promoted inhibition of the growth of all Salmonella serotypes tested (Table 1 and 2).

As for phytochemical prospecting, alkaloids and steroids were the only groups of secondary metabolites in common among the Ocotea species tested. No flavonoids (flavanones, flavones and flavonols), saponines and triterpenoids were detected in both extracts (Table 3 ).

In this regard, due to the ability of plants to synthesize a large diversity of secondary metabolites with relatively complex structures, significant antimicrobial properties have been reported in the literature, indicated by the 
presence of steroids against several strains, both Gram-positive and Gramnegative in plant extracts (CHATTOPADHYAY et al., 2001), as well as some classes of alkaloids are known for their antimicrobial properties (OMULOKOLI et al., 1997).

The ethanolic extract of $O$. silvestris presented a lower number of phytochemical compounds, being composed of alkaloids, catechins, steroids, flavononols and tannins. Tannins are compounds known for their antimicrobial effect (AKIYAMA et al., 2001), which may affect bacterial growth by inhibiting extracellular enzymes, depriving the substrates necessary for their growth or by acting directly on the inhibition of oxidative phosphorylation which comprises all metabolism (SCALBERT, 1991; SERRANO et al., 2009). The catechins, a group present in different plant species, form complexes with the bacterial cell wall and act on intestinal microorganisms, such as Salmonella (FRIEDMAN et al., 2006).

Table 3. Secondary metabolites present in leaves of Ocotea silvestris Vattimo-Gil e Ocotea diospyrifolia (Meisn.) Mez.

\begin{tabular}{lcc}
\hline Constituents & Ocotea silvestris Vattimo-Gil & Ocotea diospyrifolia (Meisn.) Mez \\
\hline Alkaloids & + & + \\
Anthocyanidins & - & + \\
Anthocyanins & - & + \\
Auronas & - & + \\
Catechins & + & - \\
Chalconas & - & + \\
Steroids & + & + \\
Phenols & - & + \\
Flavanones & - & - \\
Flavanonols & + & - \\
Flavones & - & - \\
Flavonols & - & - \\
Leucoantocianidines & - & + \\
Naponinas & - & - \\
Tannins & + & - \\
Triterpenoids & - & - \\
Xanthones & - & + \\
\hline
\end{tabular}

$(+)=$ presence of the constituent; $(-)=$ absence of the constituent

The ethanolic extract of $O$. diospyrifolia presented a larger variety containing alkaloids, anthocyanins, anthocyanins, aurones, chalcones, steroids, phenols, leucoanthocyanidins and xanthones. In the plant, phenols act in the protection against microbial infections, as well as already reported in studies related to its antioxidant potential and as antiinfectious agents, becoming a strong candidate for in-depth studies related to its potential in the industry (SALEEM et al., 2010).

It is noteworthy that there were no studies in the literature concerning antimicrobial activity with plant extracts within the genus Ocotea. Thus, our data increase the perspective for future research related to avian Salmonellosis, in addition to encouraging studies related to Brazilian flora, in order to find new bioactive compounds in plants, thus allowing the 
production of new products with antimicrobial properties.

Phytochemical prospecting detected the presence of steroids and alkaloids in both Ocotea species, which may justify the antimicrobial potential found for Salmonella serotypes.

The extracts of the species $O$. silvestris and $O$. diospyrifolia presented significant antibacterial activity in different concentrations on the serotypes of Salmonella enterica, varying according to the solvent extractor. The extract of ethyl acetate presented the best results against the tested serotypes, followed by the alcohol, aqueous and hexane extracts.

\section{REFERENCES}

AKIYAMA, H.; FUJII, K.;

YAMANAKI, O.; OONO, T.;

IWATSUKI, K. Antibacterial action of several tannins against Staphylococcus aureus. Journal of Antimicrobial Chemotherapy [online], v.48, n.4, p.487-491, 2001.

ALZOREKY, N.S.; NAKAHARA K. Antibacterial activity of extracts from some edible plants commonly consumed in Asia. International Journal of Food Microbiology [online], v.80, n.3, p.223-30, 2003.

BARRERA, E.D.B.; SUAREZ, L.E.C. In vitro anti-inflammatory effects of naturally-occurring compounds from two Lauraceae plants. Anais Academia Brasileira de Ciências [online], v.83, n.4, p.1397-1402, 2011.

BELUSSO, D.; HESPANHOL, A.N. Evolução da avicultura industrial brasileira e seus efeitos territoriais. Revista Percurso [online], v.2, n.1, p.25-51, 2010.
BONA, E.A.M.; PINTO, F.G.; FRUET, T.K; JORGE, T.C.M.; MOURA, A.C. Comparação de métodos para avaliação da atividade antimicrobiana e determinação da Concentração Inibitória Mínima (MIC) de extratos vegetais aquosos e etanólicos. Arquivos do Instituto Biológico [online], v.81, n.3, p.218-225, 2014.

CAMILOTTI, E.; ROCHA, S.L.S.; TEJKOWSKI, T.M.; MORAES, H.L.S.; NALLE, C.T.P.; AVANCINI, C.A.M. Simulação de condições de uso de quaternário de amônio frente amostras de Salmonella Hadar isoladas de carcaças de frango. Revista Brasileira de Saúde e Produção Animal [online], v.16, n.1, p.66-72, 2015.

CANSIAN, R.L.; MOSSI, A.J.; PAROUL, N.; TONIAZZO, G.; ZBORALSKI, F.; PRICHOA, F.C.; KUBIAK, G.B.; LERIN, L.A.

Atividade antioxidante e antimicrobiana de extratos de Canela-sassafrás (Ocotea odorifera (Vell.) Rowher). Perspectiva [online], v.34, n.127, p.123-33, 2010a.

CANSIAN, R.L.; MOSSI, A.J.; OLIVERIA, D.; TONIAZZO, G.; TREICHEL, H.; PAROUL, N.; ASTOLFI, V.; SERAFINI, L.A. Atividade antimicrobiana e antioxidante do óleo essencial de ho-sho

(Cinnamomum camphora Ness e Eberm Var. Linaloolifera fujita). Food Science and Technology (Campinas) [online], v.30, n.2, p.378-384, 2010 b.

CARDOSO, A.L.S.P.; TESNARI, E.N.C. Salmoneloses aviárias: revisão. Revista Brasileira Nutritime [online], v.12, n.3, p.4049-4069, 2015. 
CASTRO, R.D.; LIMA, E.O.

Antifungal activity of Brazilian sassafrás (Ocotea odorifera Vell.) and rosemary (Rosmarinus officinalis L.) essential oils against genus Candida. Brazilian Journal of Medicinal Plants [online], v.13, n.2, p.203-208, 2011.

CHATTOPADHYAY, D.; MAITI, K.; KUNDU, A.P.; CHAKRABORTY, R.; BHADRA, R.; MANDAL, S.C.;

MANDAL, A.B. Antimicrobial activity of Alstonia macrophylla: A folklore of Bay Islands. Journal of

Ethnopharmacology [online], v.77, n.1, p.49-55, 2001.

FRIEDMAN, M.; HENIKA, P.R.; LEVIN, C.E.; MANDRELL, R.E.; KOZUKUE, N. Antimicrobial activities of tea catechins and theaflavins and tea extracts against Bacillus cereus.

Journal of Food Protection [online], v.69, n.2, p.354-361, 2006.

KUETE, V.; ALIBERT-FRANCO, S., EYONG, K.O.; NGAMENI, B.; FOLEFOC, G.N.; NGUEMEVING, J.R.; TANGMOUO, J.G.; FOTSO, G.W.; KOMGUEM, J.; OUAHOUO, B.M.; BOLLA, J.M.; CHEVALIER, J.; NGADJUI, B.T.; NKENGFACK, A.E.; PAGÈS, J.M. Antibacterial activity of some natural products against bacteria expressing a multidrug-resistant phenotype. International Journal of Antimicrobial Agents [online], v.37, n.2, p.156-161, 2011.

\section{MATOS, F.J.A. Introdução à}

fitoquímica experimental. 2.ed.

Fortaleza: UFC, 1997, 141p.

MITH, H.; DURE, R.; DELCENSERIE, V.; ZHIRI, A.; DAUBE, G.;

CLINQUART, A. Antimicrobial activities of commercial essential oils and their components against foodborne pathogens and food spoilage bacteria. Food Science \& Nutrition

[online], v.2, n.4, p.403-416, 2014.

NANASOMBAT, S.;

LOHASUPTHAWEE, P. Antibacterial activity of crude ethanolic extracts and essential oils of spices against Salmonellae and other enterobacteria. KMITL Science and Technology Journal [online], v.5, n.3, p.527-535, 2005.

OLIVERO-VERBEL, J.; GONZALEZ, T.; GUETTE, J.; JARAMILLO, B.; STASHENKO, E. Chemical composition and antioxidant activity of essential oils isolated from Colombian plants. Revista Brasileira de Farmacognosia [online], v.20, n.4, p.568-574, 2010.

OMULOKOLI, E.; KHAN, B.; CHHABRA, S.C. Antiplasmodial activity of four Kenyan medicinal plants. Journal of Ethnopharmacology [online], v.56, n.2, p.133-137, 1997.

OSTROSKY, E.A.; MIZUMOTO, M.K.; LIMA, M.E.L.; KANEKO, T.M.; NISHIKAWA, S.O.; FREITAS, B.R. Métodos para avaliação da atividade antimicrobiana e determinação da Concentração Mínima Inibitória (CMI) de plantas medicinais. Revista Brasileira de Farmacognosia [online], v.12, n.2 , p.301-307, 2008.

PRIETO, J.A.; PABON, L.C.; PATIÑO, O.J.; DELGADO, W.A.; CUCA, L.E. Constituyentes químicos, actividad insecticida y antfúngica de los aceites esenciales de hojas de dos espécies Colombianas del gênero Ocotea (Lauraceae). Revista

Colombiana de Química [online], v.39, n.2, p.199-209, 2010. 
SALEEM, M.; NAZIR, M.; ALI, M.S.; HUSNAIN, H.; LEE, Y.S.; RIAZ, N.; JABBAR, A. Antimicrobial natural products: an update on future antibiotic drug candidates. Natural Product

Reports [online], v.27, n.2, p.238-254, 2010.

SCALBERT, A. Antimicrobial properties of tannins. Phytochemistry [online], v.30, n.12, p.3875-3883, 1991.

SERRANO, J.; PUUPPONEN-PIMIÄ, R.; DAUER, A.; AURA, A.M.;

NAURA-CALIXTO, F. Tannins: current knowledge of food sources, intake, bioavailability and biological effects. Molecular Nutrition Food

Research [online], v.53, n.2, p.310-329, 2009.

SILVA, F.V.M.; GIBBS, P.A. Thermal pasteurization requirements for the inactivation of Nalmonella in foods.

Food Research International [online], v.45, n.2, p.695-699, 2012.

THAI, T.H.; HIRAI, T.; LAN, N.T.; YAMAGUCHI, R. Antibiotic resistance profiles of Salmonella serovars isolated from retail pork and chicken meat in North Vietnam. International Journal of Food Microbiology [online], v.156, n.2, p.147-151, 2012.

WEBER, L.D.; PINTO, F.G.; SCUR, M.C.; DE SOUZA, J.G.; COSTA, W.F.; LEITE, C.W. Chemical composition and antimicrobial and antioxidant activity of essential oil and various plant extracts from Prunus myrtifolia (L.) Urb. African Journal of Agricultural Research [online], v.9, n.9, p.846-853, 2014.
YAMAGUCHI, K.K.L.;

ALCANTARA, J.M.; VEIGA JUNIOR, V.F. Investigação do potencial antioxidante e anticolinesterásico de 20 espécies da família Lauraceae. Acta Amazonica [online], v.42, n.4, p.541546, 2012.

Receipt date: 10/10/2017

Approval date: 28/02/2018 